\title{
Eccentric neurosurgical virtuoso: the life and times of William Sharpe
}

\author{
Roberta Rehder, MD, and Alan R. Cohen, MD \\ Department of Neurosurgery, Boston Children's Hospital, Harvard Medical School, Boston, Massachusetts
}

William Sharpe was an intriguing figure in the history of American neurosurgery. He was an extraordinarily bright and gifted man who led a flamboyant, colorful, and unconventional life. He had an international impact on the field of neurosurgery during the first half of the 20th century, yet few practicing neurosurgeons know his name. In this report, the authors discuss Sharpe's contributions to neurosurgery along with the remarkable quirkiness that came to define his professional and personal life.

http://thejns.org/doi/abs/10.3171/2015.3.FOCUS15117

KEY WORDS William Sharpe; Harvey Cushing; cerebral palsy; China; Pan-American Medical Association; Harvard Medical School; history

$\mathrm{W}$ ILLIAm James Clyde Sharpe (1882-1960) was an eccentric, brilliant, and controversial neurosurgeon with a storied career during the first half of the 20th century (Fig. 1). It is somewhat surprising, then, that so few contemporary neurosurgeons know anything about him. He trained at Harvard and Johns Hopkins, worked with Harvey Cushing and Charles Elsberg, and was one of the first physicians to dedicate his medical practice exclusively to neurosurgery. Nominated by Charles Eliot, president of Harvard University, to be professor of surgery in Shanghai, he worked for 2 years in China, where he operated successfully on the son of the Chinese emperor. ${ }^{1}$

Sharpe had an international presence and met Hitler, Stalin, and Roosevelt. He founded the Pan-American Medical Association and served as its inaugural president. $\mathrm{He}$ authored two of the earliest textbooks on neurological surgery and made contributions to the management of trauma and cerebral palsy. He was an early civil rights activist and made powerful philanthropic contributions to support African American school teachers and underprivileged children.

Despite his many talents, Sharpe was a particularly odd individual. He was often impulsive and pugnacious. As a child, he belonged to a gang in the slums of Philadelphia. As a trainee in Baltimore, he almost slugged his mentor, Harvey Cushing, during a disagreement. His judgment was often impaired by alcohol, and he once lost a patient while operating under the influence in Cuba. His relationships with women were stormy and tempestuous. His personality was strong, and he even took it upon himself to perform an autopsy on his older brother. He was extremely self-confident and equally self-critical.

Here we recount the life and times of this most unusual individual, who played a role in the founding of modern neurosurgery. Some of the most intriguing stories were gleaned from his own highly entertaining autobiography, Brain Surgeon, which he wrote in 1952 at the age of 70,7 years before his death. ${ }^{31}$ [Authors' note: unless otherwise noted, all quotations are taken from this work.] 


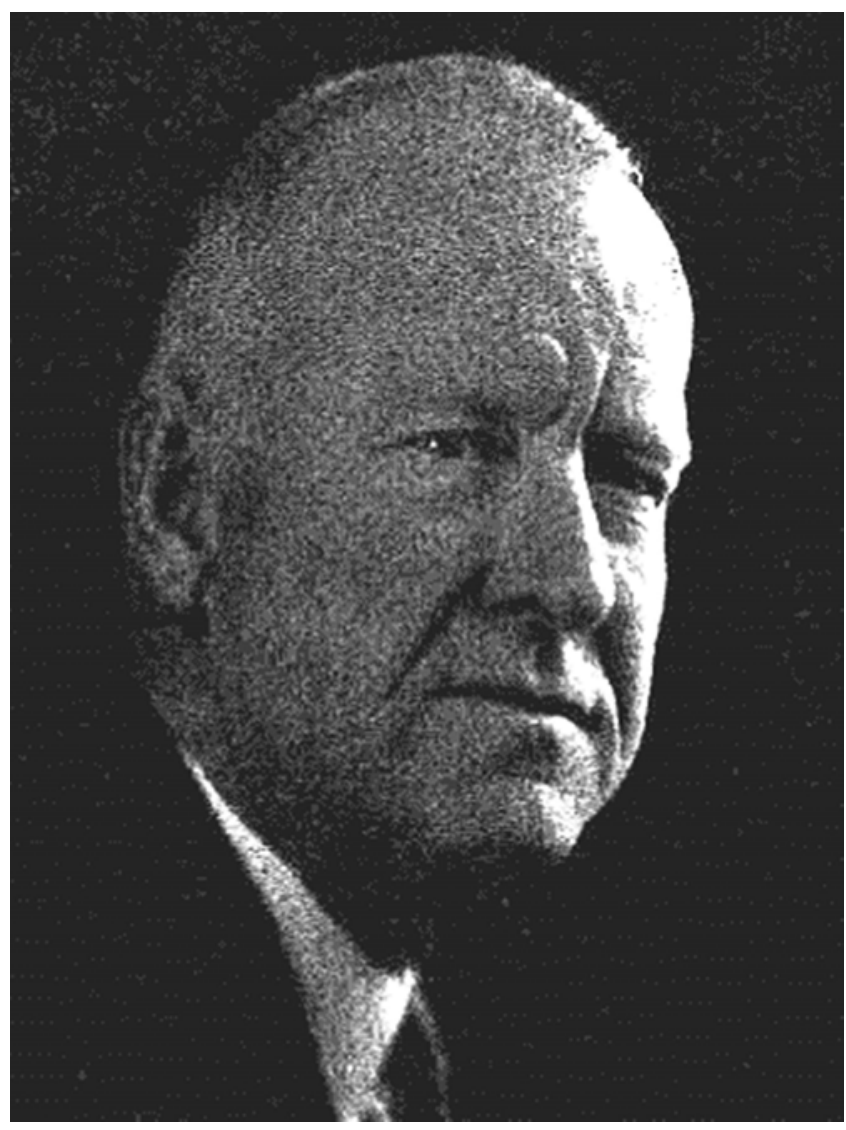

FIG. 1. William James Clyde Sharpe (1882-1960). Courtesy of Wolters Kluwer Health.

\section{Early Years}

William James Clyde Sharpe, known to his family as Clyde, was born in Pittsburgh, Pennsylvania, on December 6, 1882. ${ }^{3}$ His father was a Scottish Presbyterian clergyman, and his mother worked actively at the church, organizing mission groups and teaching Sunday school. Sharpe's father had 7 brothers, each of whom was a physician. Sharpe was the youngest of 3 brothers. Their father coaxed each of them to pursue a career as a preacher, as he himself had done, but none followed in his footsteps. Eugene, the oldest, and Norman, both went on to careers in medicine. Norman, in fact, became a neurosurgeon.

By decree of their somewhat tyrannical father, the boys attended church twice a week and 5 times on Sundays. The family would awaken early on the Sabbath, and the daily activities were focused on bible reading and prayers. Because all of this was forced on him, young Sharpe learned to detest Sundays.

On Sunday afternoons, Sharpe and his brothers and their friends would sneak up to the attic to play various games. One of the more notable games was flycatcher. In the summertime, they would leave the windows open and try to catch as many flies as possible. The one who caught the smallest number of flies was the loser and, as a punishment, had to eat one dead fly selected from the winner's pile. According to the ritual, the loser had to bite off its head, chew it, swallow it and then eat the rest. Since
Sharpe was usually the youngest present, he became the fly-eater champion.

Sharpe often associated his childhood memories with poverty, alcoholism, and disease. His family lived in the slum areas of Pittsburgh, Chicago, and Philadelphia. On Saturday evenings, Sharpe's father would routinely bring homeless and intoxicated men to the house for dinner and prayer. He then let them sleep on cots he had prepared in the basement. There were 12 cots in total, and each had a blanket. ${ }^{31}$

In his early teens in Philadelphia, Sharpe was member of a gang, the "Ram Cat." There were 12 boys in the gang. Among them was a single black boy, Archie Norris, who became Sharpe's best friend. Sharpe felt that Archie was the brightest and most athletically gifted of the group, but had no opportunities for furthering his education. He ended up the proprietor of a shoeshine parlor. Through his close friendship with Archie, Sharpe learned early on of the injustices faced by blacks in America, leading him to direct his philanthropy later in life to the fight against racial discrimination.

During his last years of high school, Sharpe chose to pursue a career in medicine. His two older brothers, Eugene and Norman, had graduated from Jefferson Medical School. Sharpe's father continued to hope that one of his sons would join the ministry, so it was some time before Sharpe told his father about his career plans. While still in high school, Sharpe spent Wednesday afternoons attending the surgical clinic of the famed W. W. Keen, fascinated by hearing him discuss the cranial cases he carried out with a hammer and chisel.

Sharpe was active on the baseball team in high school and was a powerful member of the crew team. He was planning to attend college at the University of Pennsylvania but won a scholarship to Harvard when the crew scouts watched him compete. One reason he chose to go was to escape the dreaded weekly family ritual of the Sabbath back home.

Sharpe entered Harvard University in 1900 with $\$ 100$ in his pocket given to him by his mother, who had borrowed it from her brother in Denver. The tuition for the semester was \$75, and Sharpe was living large, with free meals provided to him by the crew team. However, things quickly took a turn for the worse, as the English sculling stroke used at Harvard was dramatically different from the stroke Sharpe had learned in high school. Despite valiant efforts to learn the new stroke, Sharpe was unable to make the change and was kicked off the crew team after 3 weeks.

Losing his scholarship created a minor financial crisis for Sharpe, which he ultimately solved by tutoring students at Harvard for a fee. He began tutoring for a course in hygiene, and was hugely successful. Of 46 students Sharpe tutored, all but one passed the exam, and the one who failed had fallen asleep during the test. He offered a money-back guarantee for anyone who did not pass, which increased his popularity enormously. Sharpe was so successful as a tutor in college, medical school, and the years of internship that he accumulated $\$ 50,000$ in earnings over a 10-year period. As he described it, "...four years of my medical school studies and the three years of hospital internship, and my total income from this source for the 
ten years amounted to approximately fifty thousand dollars."

At Harvard, Sharpe lived in the Divinity Hall, fulfilling the wishes of his father. There he was introduced to John Haynes Holmes, a prominent Unitarian minister and cofounder of the National Association for the Advancement of Colored People (NAACP) and the American Civil Liberties Union (ACLU) [Roger N. Baldwin: John Haynes Holmes-preacher and prophet 1879-1964: an address given on the occasion of the memorial service given by the Community Church of Boston (nonsectarian) Sunday, May 3, 1964. (http://id.lib.harvard.edu/aleph/001747566/ catalog)]. Holmes had a profound influence on Sharpe in the years to come. At the Divinity Hall, friends referred to Sharpe by using his two middle initials, J. C. (James Clyde), after two uncles. Subsequently they began calling him Jesus Christ, and he wanted no part of that, so Sharpe finally eliminated the middle initials.

In the fall of his 2 nd year, Sharpe began playing lacrosse, attempting to join the Harvard team. However, he ultimately had to give up that pursuit because of an illness characterized by recurrent fatigue, chills, and fever every 3-4 days. The college doctor prescribed a tonic and laxative, which had no effect. The illness went on for months and Sharpe had difficulty staying awake for morning classes. A classmate suggested a stiff drink of whiskey each morning, which Sharpe tried and found so effective that he continued it for weeks until he determined that he was becoming addicted to alcohol and discontinued the practice. Another classmate, hearing of Sharpe's symptoms, suggested the diagnosis of malaria, which was subsequently confirmed on a blood test at the Massachusetts General Hospital (MGH). He was treated with quinine and recovered in the ensuing months.

Sharpe spent his final year of college in Europe, studying at the University of Berlin. Although he had done well in his German language studies in high school and college, he had difficulty mastering the language in classes and was frequently referred to as the "Amerikanischer Schwein" (American pig) during the first few months. He subsequently traveled throughout Europe and spent almost 5 months trying to write his thesis in a small house overlooking the sea in Levanto, Italy. He rented a space there and lived with the three occupants, Annunciata, a widowed mother in her 20s, her 4-year-old daughter, and her mother, none of whom spoke any English. Sharpe became infatuated with Annunciata and proposed marriage, hoping to bring her and her daughter with him back to America, but she declined and he returned home without finishing his thesis.

Sharpe graduated from Harvard College in 1904 and spent the next 4 years at Harvard Medical School, studying under such giants as Walter Bradford Cannon, Maurice Richardson, Reginald Fitz, and Richard Cabot. In his 2nd year, he served as a prosector in the anatomy course, under the supervision of Professor Thomas Dwight, where his job was to arrange the dissections for the 1st year students the night before. He remembered accidentally severing the sciatic nerve while preparing a demonstration of the muscles of the thigh, and trying to cover it up by suturing the cut ends of the nerve and covering over the error with overlying fascia, but he was found out by Dwight, who called him before the class to demonstrate what a surgeon should not be. Nevertheless, Sharpe remained captivated by the field of surgery, particularly neurosurgery, and never wavered in choosing it as a future career.

Sharpe's lifelong impulsivity continued to follow him in both his professional and personal life. Despite his rigorous schedule at the medical school, his personal life did not lack for amorous adventure. One spring evening during his 3rd year, after working in the cadaver lab, he met a charming young woman named Betty while waiting to return to Cambridge at the trolley stop at Boylston Street and Massachusetts Avenue. She was carrying a large paper bag filled with bottles of beer, but the bag broke and the beer bottles shattered on the street. Sharpe bought her more beer at a corner store, and she invited him up to her third floor apartment, which she shared with her roommate. There the three of them consumed the beer and bought more beer to drink. Sharpe recalled:

I never could remember much of the rest of that night. But at daybreak I suddenly awoke to find myself in the middle of a double bed with a girl sound asleep on each side of me. Frantically I jumped out of bed, put on my clothes, and arrived at the medical school ahead of the janitor - the earliest arrival of my entire four years there. I resolved that such a thing would never happen again.

It turned out that Betty had previously been in a 3-year affair with a young surgeon from MGH. That relationship was fueled by alcohol, and ultimately the surgeon lost his appointment at MGH and Harvard Medical School. From its beginning, Sharpe realized his own relationship with Betty would be complicated: "I knew I was playing with fire." Sharpe carried on a yearlong affair with Betty but decided it would have to end when he would leave for New York City to do his internship at Roosevelt Hospital.

During the spring of his 4th year of medical school, Sharpe had to go to New York to sit for the entrance exams for his internship. He was planning to return to Boston on a Saturday to spend time with Betty, but he got done early and decided to surprise her with a visit at midnight on Friday. Sharpe was flabbergasted to find her in bed with another man. He went berserk, pummeling the man with his fists and hurling him down the stairs and out onto the street, rendering him unconscious. Sharpe recalled his almost murderous rampage, "In those days I was built something like a bull-and I acted like one." The man ultimately recovered, and Betty left Boston for a secretarial post in another New England town. Sharpe graduated from Harvard Medical School in 1908 and moved to New York City to begin a 2-year internship at Roosevelt Hospital. ${ }^{1}$

Since there was a 6-month hiatus before the internship began, Sharpe decided to go to Baltimore for an externship at Johns Hopkins, where he was overwhelmed by the academic firepower of the "Big Four": William Henry Welch, William Stewart Halsted, William Osler, and Howard Kelly. ${ }^{27} \mathrm{He}$ was initially assigned to the Department of Urology under Hugh H. Young. His focus on neurosurgery really began after observing Cushing in the operating room:

Within the first month the work of Dr. Harvey W. Cushing interested me more and more, and when a vacancy appeared 
in his department I quickly applied for it. Luckily, I was permitted to transfer to it. First I worked in the Hunterian Laboratory, and then as one of Dr. Cushing's assistants in the hospital.

Before leaving Baltimore, Sharpe applied for a position as Cushing's assistant 2 years in advance and returned to work with him after his 2-year internship at Roosevelt Hospital.

\section{Internship at Roosevelt Hospital}

Sharpe began his 2-year surgical internship at Roosevelt Hospital in 1909. He immediately noticed that patients with head trauma received only cursory care at Roosevelt. On Cushing's service at Hopkins, head trauma patients were carefully studied, and surgical intervention was carried out early in cases of suspected increased intracranial pressure. The trauma service at Roosevelt was a lot busier, and much of the management was expectant, with observation and an icebag to the head. Sharpe observed, "I found myself becoming increasingly indignant in those days at the way acute brain injuries were handled."

Sharpe suffered quite a scare that began during dinner at the hospital on Thanksgiving Day in 1910. He was called to resuscitate a patient who had developed a respiratory arrest, having undergone thyroid surgery earlier in the day. The patient was saved, but ended up coughing into Sharpe's face several times during the resuscitation. That night, while Sharpe was at the Metropolitan Opera listening to Caruso in Aida, he developed a burning sensation in his eyes. Later that night he developed conjunctival swelling with pus. Sharpe awakened the junior pathological intern who made a smear and diagnosed gonococcal conjunctivitis. Three other interns, who had been awakened, confirmed the diagnosis. Sharpe was placed on bed rest and given topical silver nitrate treatment. He recalled the sizzling pain from the silver nitrate application, followed by complete loss of sight in both eyes and severe periorbital swelling. Sharpe became distraught and contemplated suicide. Fortunately, the next morning the attending ophthalmologist came by and reviewed the slide, which showed only pneumococcus. The topical silver nitrate treatment was discontinued, with complete return of vision and resolution of the inflammation over the next 10 days. Sharpe was able to move on and go to work with Cushing after several weeks.

\section{The Cushing Influence}

In 1911, Sharpe returned to Baltimore to assist Cushing for almost a year. At that time, Walter Dandy was a junior intern assigned to the Hunterian Laboratory. Before leaving Roosevelt Hospital, Sharpe was advised by George E. Brewer about Cushing's explosive temper: "A creative genius usually works under severe tension to a degree that even apparently trivial matters assume an importance far beyond their actual significance."

Sharpe had a turbulent relationship with Cushing that began on his 1st day at the job. He reported to the Hunterian Laboratory on New Year's Day, where he found Cushing in the process of removing the posterior lobe of the pituitary gland from a dog. Cushing instructed Sharpe to go immediately to a funeral parlor in Washington, DC, and perform an autopsy on one of his patients with gigantism. Cushing asked him to retrieve the ductless glands (pituitary, thyroid, parathyroids, and adrenals) along with the brain, heart, lungs, kidneys, pancreas, and testicles. He was also to deliver a $\$ 50$ to tip the Polish priest, who had arranged permission for the postmortem examination. The mission had to be carried out quickly, as the funeral service was set to begin at $2 \mathrm{pm}$.

Sharpe arrived in Washington in the late morning and met the priest in the front office. Sharpe recalled, "He (the priest) then opened the door of a high, thin-walled partition in the rear, and there in the center of a gas lighted room was the longest and deepest coffin I had ever seen."

The body was so heavy that Sharpe was unable to lift it out of the coffin, and the priest refused to help him. He performed the autopsy in the coffin, with the impatient and unknowing family and friends in the next room. After securing his payment, the priest notified Sharpe that he had not obtained the family's permission for the postmortem.

In doing the autopsy, Sharpe had made a tactical mistake. He removed the abdominal organs first, and thus had to saw the thickened skull and perform a noisy craniotomy in a coffin with the guests sitting in the next room. The crowd grew angrier, but Sharpe ultimately completed the task at the last minute and ran out the back door to return to Baltimore in a taxi, which sped away as a member of the congregation hit it with a rock. When he returned, Sharpe placed the tissues in a refrigerator and, feeling pleased with himself, phoned Cushing and told him that the mission had been accomplished,

The following morning, before daylight, Sharpe was awakened from his bed by a rough tug on his shoulder from a furious Cushing, who scolded him that he had missed the left parathyroid gland. Despite Sharpe's explanation that he had been forced to do the autopsy in a coffin and had, in fact, never seen a parathyroid gland, Cushing became more annoyed: "When I tell you to do a job, you are to do it!" Cushing told Sharpe that he had chosen the wrong profession, whereupon he discharged Sharpe from the service and stormed out of the room, leaving Sharpe in tears. An hour later, Sharpe was overhead-paged to meet with Cushing at the Hunterian, where Cushing demonstrated to him the anatomy of the parathyroids and asked him to take a history on a new patient, never mentioning again that he had just fired Sharpe earlier that day.

Sharpe's year at Hopkins under Cushing was highly educational, but equally strenuous. On one occasion, the two men almost came to blows. ${ }^{1}$ Sharpe had frequently found himself the object of Cushing's hot temper. In his most serious conflict, Sharpe described the time that he was about to slug his mentor. Cushing had been in the process of placing a dressing on one of his postoperative patients with a fungating malignant brain tumor, with Sharpe and a nurse at his side. Cushing was called away to see a patient elsewhere in the hospital, and instructed Sharpe to stay at the patient's bedside until he returned. The patient was barely conscious and Sharpe placed a sterile towel over the fungating mass and waited for Cushing. After waiting for two hours, Sharpe thought Cushing had forgotten about the patient and instructed the nurse to stay at 
the bedside while he went out in search of his boss. Sharpe was unable to find Cushing and returned in 10 minutes to find an enraged Cushing at the bedside with the patient having been left alone. The nurse had gone next door to deal with another patient who had a generalized seizure. Sharpe recalled Cushing's anger:

Dr. Cushing roared at me. 'Didn't I tell you to remain here until I returned?' I admitted, 'Yes, sir, you did. 'I did remain here for almost 2 hours. Then I asked the nurse to remain while I-.'

'Don't blame it on the nurse,' he snapped. 'You're yellow!' With that, I forgot all about the great Dr. Cushing and my ambition to become a neurosurgeon. Impulsively I grabbed his right shoulder with my left hand and almost struck him with my right fist. ${ }^{31}$

Cushing finished dressing the wound and left without saying a word. The nurse was in tears and Sharpe was devastated. Later in the day, Cushing phoned Sharpe and invited him to dinner at his home, but Sharpe was too emotionally drained and declined. He reported no further outbursts from Cushing after that event.

Sharpe found Cushing to be as tenacious outside the hospital as he was on the wards. Each summer there was a baseball game held at the Baltimore Country Club, pitting the Harvard and Yale graduates of the entire medical staff against one another. Sharpe had been a good ballplayer in high school, college, and medical school and was drafted to be the pitcher for the Harvard team. Cushing had been a legendary second baseman during his undergraduate years at Yale, where he had served as captain of the team. When the two teams faced off, Sharpe, Cushing's junior assistant, managed to strike out his mentor during his first time at bat. None too happy about this, Cushing threw down his bat in disgust. Sharpe's teammates were overjoyed and did not hide their elation. Unfortunately for Sharpe, though, Cushing was not to be daunted and reached second base on each of his next 3 times at bat.

Against Cushing's advice, Sharpe chose to go to work in the "Harvard Unit" in China. Charles Eliot, president of Harvard, had nominated Sharpe as the first Harvard professor of surgery in Shanghai. Cushing told Sharpe that it would be a mistake to go and that he would be throwing away his future in neurosurgery. Despite Cushing's disapproval, Sharpe resigned his position at Hopkins and moved to the Orient.

\section{China}

Before the early 1900s, medical missionaries were the only persons to carry out western medical education in China. The quality of the medical training varied, mostly because of the lack of sufficient equipment, money, and qualified trained teachers to do the work. ${ }^{16}$

In 1907, a group of Harvard medical students gathered at the Wayside Inn, in Sudbury, Massachusetts, to discuss ways to practice medicine in China. The students proposed the establishment of a medical school in China and presented the project to president Eliot of Harvard on April 29, $1908 .{ }^{16}$ Eliot then assigned Martin R. Edwards, a Harvard medical graduate, to visit the country and evaluate its conditions. ${ }^{18}$ According to Edwards, the institution should optimally be established in Shanghai. Its main purposes would be to teach modern medicine to Chinese students, help the government reform the hygiene system, and study local diseases that threatened the health of the world's population, such as bubonic plague, cholera, and leprosy. ${ }^{6}$

Harvard Medical School of China opened its doors in 1911 and remained as a functional institution for 5 years (Fig. 2). The term of medical school training was 5 years and the teaching was in English. ${ }^{7,28}$ Sharpe recalled Eliot's invitation:

Remembering my tutoring activities and my pleasant relationship with the Chinese students during the summer of 1906, he offered to appoint me the first professor of surgery there, beginning January first of the coming year, 1912.

Sharpe and his classmates, who had been assigned to China, were all inexperienced surgeons. He recalled,

No one on the faculty was over 30 years old... Not one of us had ever practiced outside a hospital and each had served as an intern for only 1,2, or 3 years. Now we were on our own...

During that year, Sharpe wrote his first neurosurgical paper, entitled, "The operative treatment of fracture of the skull," published in the China Medical Journal. ${ }^{37}$

In China, Sharpe had a brush with royalty. He was

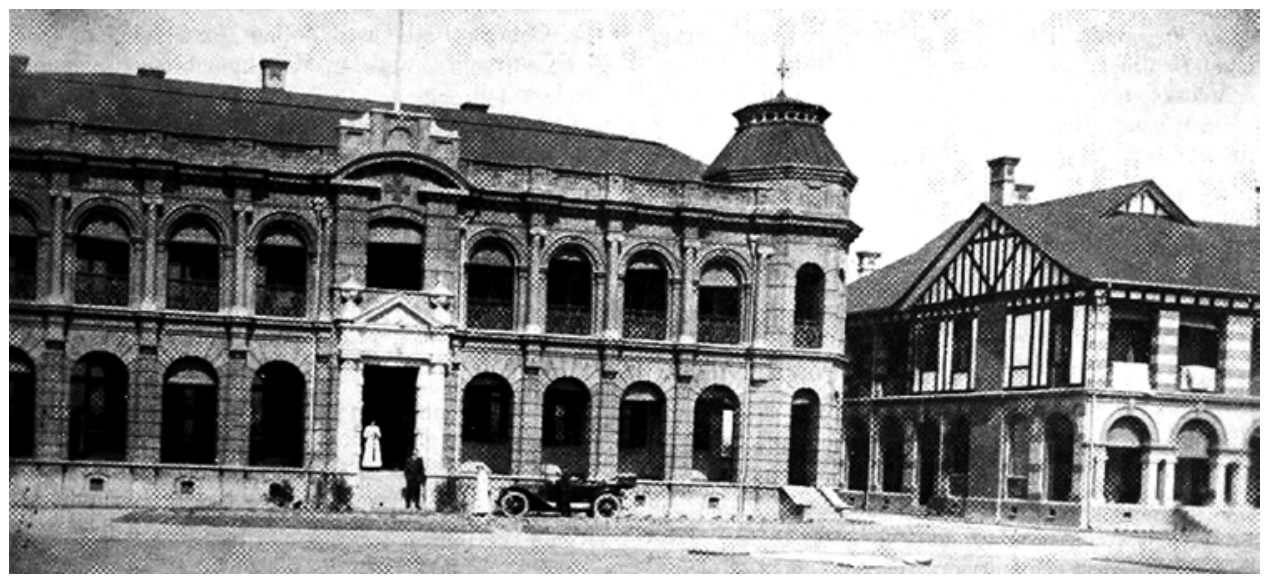

FIG. 2. Harvard Medical School of China, Shanghai, 1911-1916. Public domain. 
summoned to Peking to evaluate the oldest son of Yuan Shikai (1859-1916) (Fig. 3), the "Chinese emperor" and first president of China, following the Manchu Dynasty. Yuan's son had fallen off a horse and developed neck stiffness and paralysis of the left arm and leg. The local medical team had diagnosed a cervical spinal cord injury. However, when Sharpe examined the patient he also noted leftsided facial weakness. He surmised that the problem was higher up, a hemorrhage compressing the right side of the brain. ${ }^{16}$ Sharpe recommended a trephine on the right side of the skull. But the Chinese surgeons were reluctant to permit this, since they would lose face if it was determined that their diagnosis was incorrect. Instead, they reached a compromise with Sharpe, suggesting to the family that the hemiplegia was due to an injury to both the spinal cord and brain.

One factor that helped the Chinese doctors change their minds was that Sharpe, while waiting for permission to operate, resorted to medical measures, which included the use of Epsom salts. The chief Chinese physician finally agreed to proceed with the surgery, and begged Sharpe to stop the Epsom salts, for important personal reasons. Because of the real fear of assassination of royalty by poison in food or medicine, the patient's mother always insisted on two identical trays of food. One of them, always selected by her, would be eaten by her son and the other by

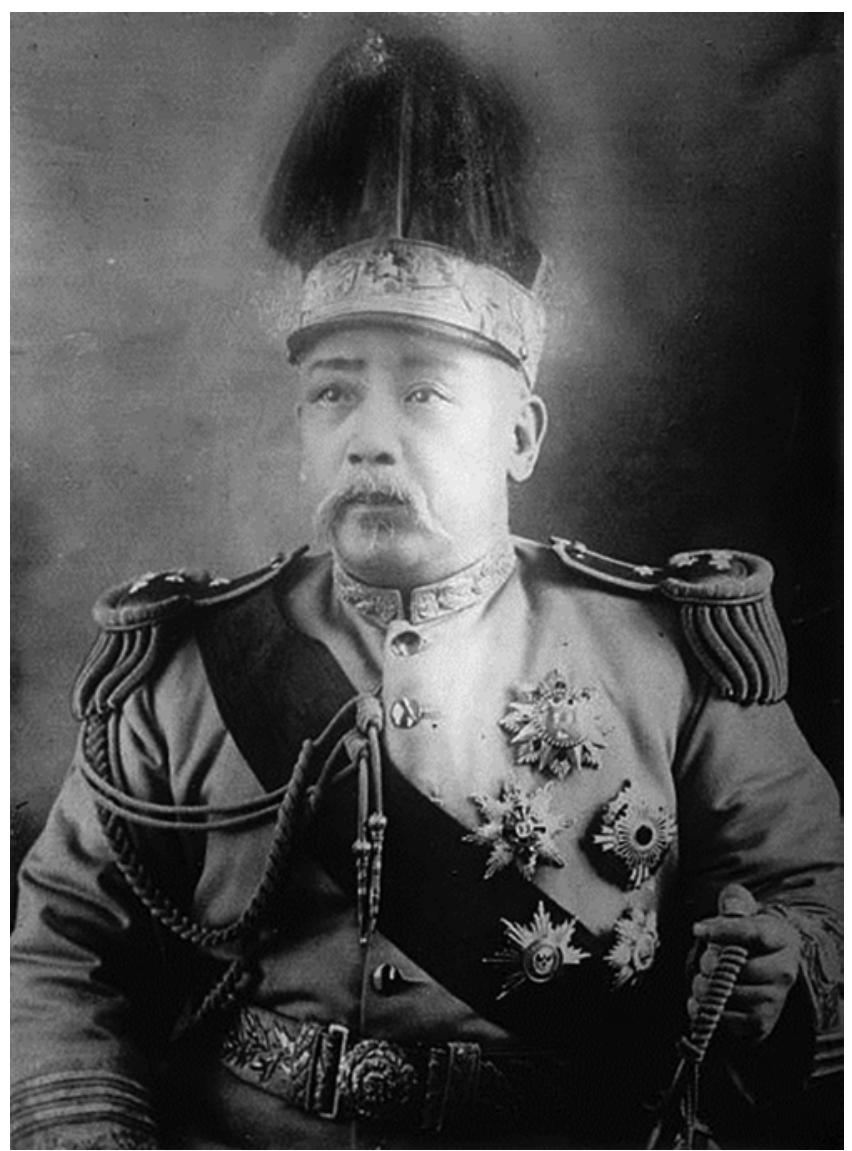

FIG. 3. Yuan Shikai, the first president of the Republic of China, 1912. Sharpe operated on his son, diagnosing and successfully removing an extraaxial hematoma, which he sustained in a fall from a horse. Public domain. the cook, in her presence. The same was true for medicine, which is why the chief physician was overwhelmed by the necessity of taking daily doses of Epsom salts himself and begged for the medication to be stopped.

It was still some time before the mother consented to the surgery. When she finally came around, the procedure was carried out in the patient's bedroom under local cocaine anesthesia. Sharpe described the procedure, in which he drained an extraaxial hematoma:

I injected the local anesthetic beneath the shaven side of the right parietal area and made a simple linear incision about two inches long. Then I inserted a small retractor on each side of the incision, and let the German doctor hold one and the Frenchman the other. As the scalp incision was drawn back, almost a tablespoonful of dark red blood clot was exposed. When the clot was removed, I could see a linear fracture of the underlying vault of the skull, over one-eighth of an inch in width. Protruding through this open crack was more semisolid clot. I began pulling out this semiclotted blood with a small pair of forceps. Each time some of it was removed from the open line of fracture, more of it was pushed upward by the increased pressure within the skull. So I kept on removing. This procedure continued until at least four tablespoonfuls of semisolid blood clot had been removed, and then almost two ounces more welled out. Hoping that this escape of blood clot might be sufficient to relieve the pressure on the motor area of the brain, I decided to let well enough alone. Instead of making a trephine opening to look in and see, I inserted a small rubber drain at each end of the incision, which I loosely sutured with silk thread.

After the operation, the patient soon recovered his leftside strength and Sharpe was treated as a god who had brought to life the "dead" side. To express gratitude for the surgical procedure, the family sent Chinese girls to Sharpe's room every night. The emperor asked Sharpe to remain in China and serve as his own private doctor and also gave Sharpe an envelope with $\$ 50,000$ as compensation for his work. Sharpe ultimately resigned his position in China and returned to the US in 1912.

\section{Neurosurgery in New York City}

Sharpe returned to the US and dedicated his medical practice exclusively to neurosurgery. He initially worked at the private hospital of William T. Bull as night resident [Haesicke C: The Records of the House of Relief, New York Hospital (1875-1919) in the Medical Center Archives of NewYork-Presbyterian/Weill Cornell, 2012, p 7 (http:// weill.cornell.edu/archives/pdf/institutional_aids/House ofRelief.pdf)]. Subsequently, he became a clinical assistant at the Neurological Institute on East 90th Street on the service of Joseph Collins. ${ }^{28}$ There he subsequently worked for the legendary Charles Elsberg for 2 years. Sharpe recalled Elsberg's words, "General surgery is my bread and butter, but neurosurgery is my true love."

In the early 1900 s, the surgeons whose practice was exclusively dedicated to neurosurgery were Victor Horsley in London and Thierry de Martel in Paris. In the US, there were Harvey Cushing, Charles Frazier, Walter Dandy, Alfred Adson, Howard Naffziger, Ernest Sachs, and William Sharpe. Sharpe envisioned the creation of a neurosurgical department and emphasized the need for neurosurgical training in medical schools and residency. 
Ultimately, Sharpe became an active member of the Polyclinic Medical School and Hospital, which had been founded in $1882 . .^{24,29}$ Sharpe was introduced to John A. Wyeth, chairman of the Department of Surgery at the Polyclinic. ${ }^{2}$ Thanks to Wyeth's support, he was able to create a Department of Neurosurgery at the Polyclinic. His older brother Norman Sharpe, a neurosurgeon who worked with John Chalmer DaCosta in Philadelphia, joined him in 1915 , focusing his practice on the treatment of spinal pathologies. ${ }^{14,29}$

Sharpe spent most of his career as chairman of the Department of Neurosurgery at the New York Polyclinic Hospital. He also had appointments at the Manhattan Hospital and worked in private clinics. He shared an office with Foster Kennedy, Ramsey Hunt, and Frederick Peterson for almost a decade, until 1928, when the hospital was razed to make way for the Rockefeller Center. ${ }^{29}$

In 1920, Sharpe published his first textbook, entitled Diagnosis and Treatment of Brain Injuries (Fig. 4). ${ }^{32}$ In 1928, he and his brother Norman coauthored a more complete and illustrated version, Neurosurgery: Principles, Practice, and Treatment (Fig. 5). ${ }^{33}$

Sharpe's main interest focused on the treatment of cerebral palsy. His belief was that the disorder was caused by untreated intracranial hemorrhage at birth. In selected

\section{DIAGNOSIS AND TREAT- MENT OF BRAIN INJURIES}

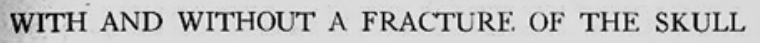

BY

WILLIAM SHARPE, M.D.

PROFESSOR OP NEUROLOGIC SURGERY, NEW YORK POLYCLINIC MEDICAL. SCHOOL AND MOSPTAL CONSULTING NEUROLOGIC SURGEON, MANHATTAN EYT AND EAR HOSPITAL, HOSPITAL
FOR RUPTUKED AND CRIPPLED, BETH ISRAEL HOSPITAL, NEW YOKK CITY AND NASSAU HOSPITAL, MINEOLA, LONG ISLAND, ETC, ETC.

2SE ILLUSTRATIONS

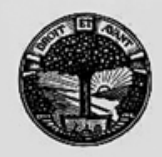

PHILADELPHIA AND LONDON J. B. LIPPINCOTT COMPANY

FIG. 4. Sharpe's neurosurgical textbook, Diagnosis and Treatment of Brain Injuries, 1920. Public domain.

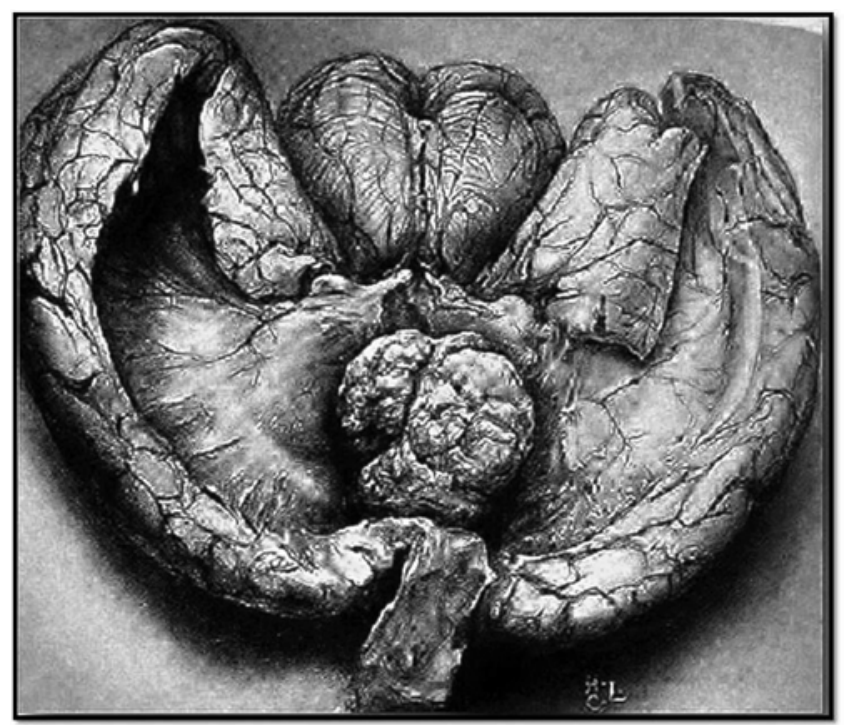

FIG. 5. Sharpe's illustration of a brain tumor from Neurosurgery: Principles, Practice, and Treatment, 1928. Courtesy of Lippincott Williams \& Wilkins.

cases, Sharpe advised subtemporal decompression to relieve spasticity. He reported the results of 60 children with cerebral palsy who underwent subtemporal decompression. Although 15 of them died after surgery, he observed that spasticity was reduced in the survival group after 3-6 months of follow-up. ${ }^{34}$

On November 15, 1915, Sharpe presented his case series on the treatment of cerebral palsy at the Joint Meeting of the New York Neurological Society and the Academy Section of Neurology and Psychiatry. ${ }^{34}$ At the event, two rooms were reserved for his presentation: one room was for the parents and children who had survived surgery and a second room, in which 15 brain specimens were displayed in jars. Sharpe also presented motion pictures that illustrated the postoperative recovery (Fig. 6). The meeting became known as a "public spectacle" and made newspaper headlines throughout the country (Fig. 7).12,26

The reaction of the medical community to Sharpe's novel treatment proposal was mixed. William Leszynsky, a neurologist, criticized Sharpe, mentioning that the condition was hopeless from the very beginning and "it was absurd to relieve this condition by a cranial operation." 31,39 Another critical argument came from a noted obstetrician who said, "Dr. Sharpe is trying to subvert the will of God. These children were born this way and are doomed to remain so." ${ }^{31}$ Ramsay Hunt congratulated Sharpe for his efforts in the treatment of cerebral palsy, a condition he described as a "discouraging group of cases." ${ }^{36}$ Following the "public spectacle," Sharpe's popularity increased, and his future adventures constantly made news headlines., ${ }^{4,19-21}$

Among Sharpe's patients was a 15 -year-old girl with cerebral palsy whose sister, Josephine, later became Sharpe's wife. Josephine (Jo) later worked avidly with Sharpe, helping with the social service care of children with cerebral palsy. The couple had a single son, Bill, about whom Sharpe wrote very little.

Sharpe was also concerned with the management of posttraumatic brain injury. He emphasized the importance 

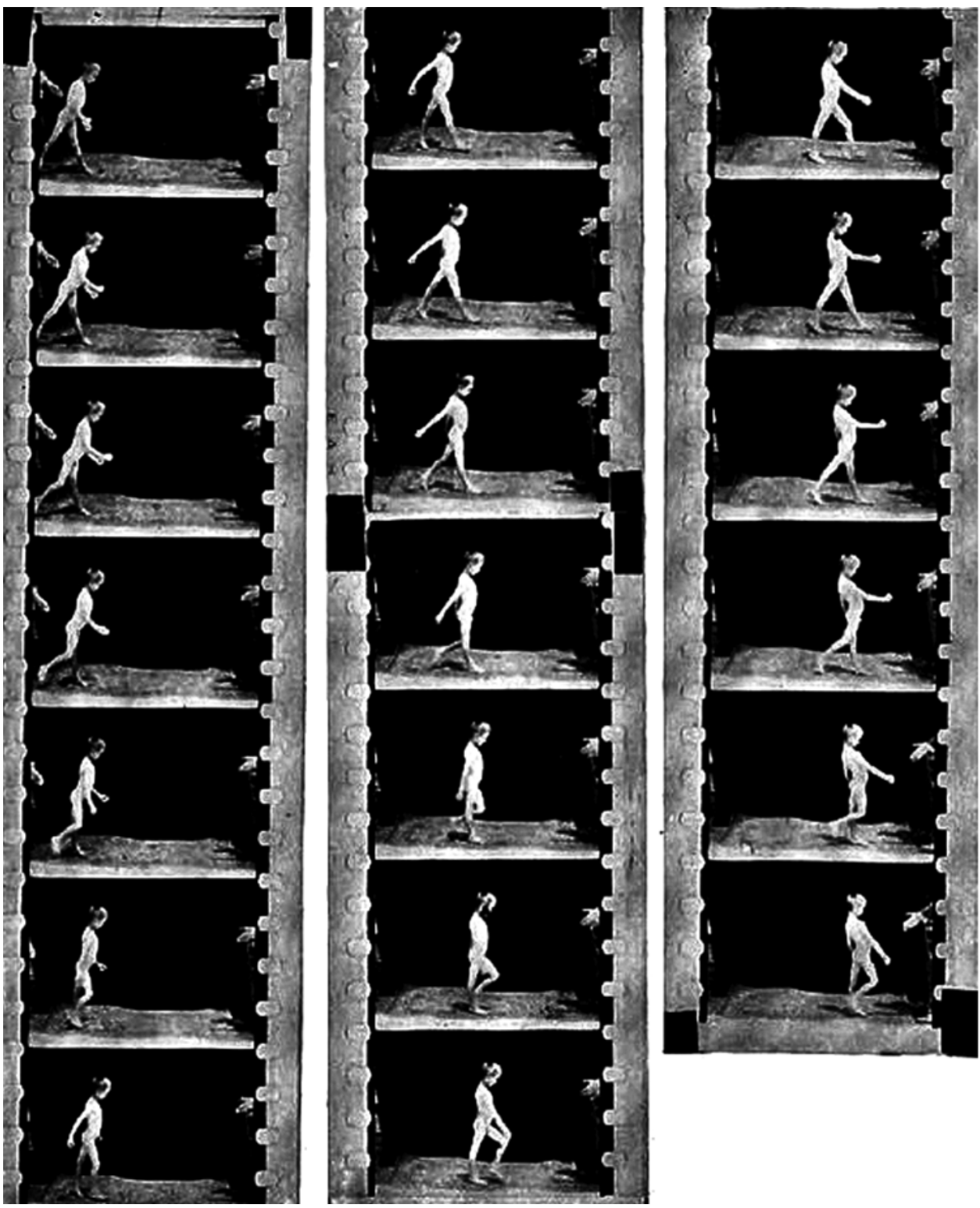

FIG. 6. Sharpe's motion picture demonstrating the recovery of a child after treatment of cerebral palsy. Diagnosis and Treatment of Brain Injuries, 1920. Public domain.

of the clinical examination in the diagnosis of raised intracranial pressure and detailed a surgical treatment regimen for skull fractures (Fig. 8) and intracranial hemorrhage..$^{38}$ Following World War I, Sharpe believed that the threshold for surgery in closed head injuries was set too high..$^{11} \mathrm{He}$ believed that the high mortality rate of posttraumatic cranial trauma was due to delayed cranial decompression. ${ }^{35}$

\section{Hitler and Stalin}

In 1934, Sharpe was invited by the Russian government to deliver several lectures on neurosurgery and to demonstrate operative techniques, particularly on the management of cerebral palsy. On his journey to Russia, he met two of the most powerful dictators in history, Adolf Hitler and Josef Stalin.

On his way to Russia, Sharpe stopped in Germany to meet his former Harvard Club friend Ernst "Putzi" Hanfstaengl. Hanfstaengl had developed the reputation as "Hitler's confidant." ${ }^{30}$ In Berlin, Hanfstaengl introduced Sharpe to Adolf Hitler, Hermann Göring, and Joseph Goebbels (Fig. 9). Sharpe's recollection was that Hitler was "unbelievably tense" and spoke in a high staccato voice. Sharpe recalled him as "mildly maniacal, and unless he quiets down, he is going to break." He described Göring as affable and Goebbels as frail and nervous, with a cold repellent personality.

Putzi was the son of a wealthy German art publisher, Edgar Hanfstaengl, and an American mother, Katharine Wilhelmina Heine, and considered himself "half-American." Putzi, a gifted piano player, graduated from Harvard and moved to New York City to run the family gallery on Fifth Avenue. ${ }^{17}$ In 1917, he was suspended from the Harvard Club as a pro-German, "Hun." Putzi later became 


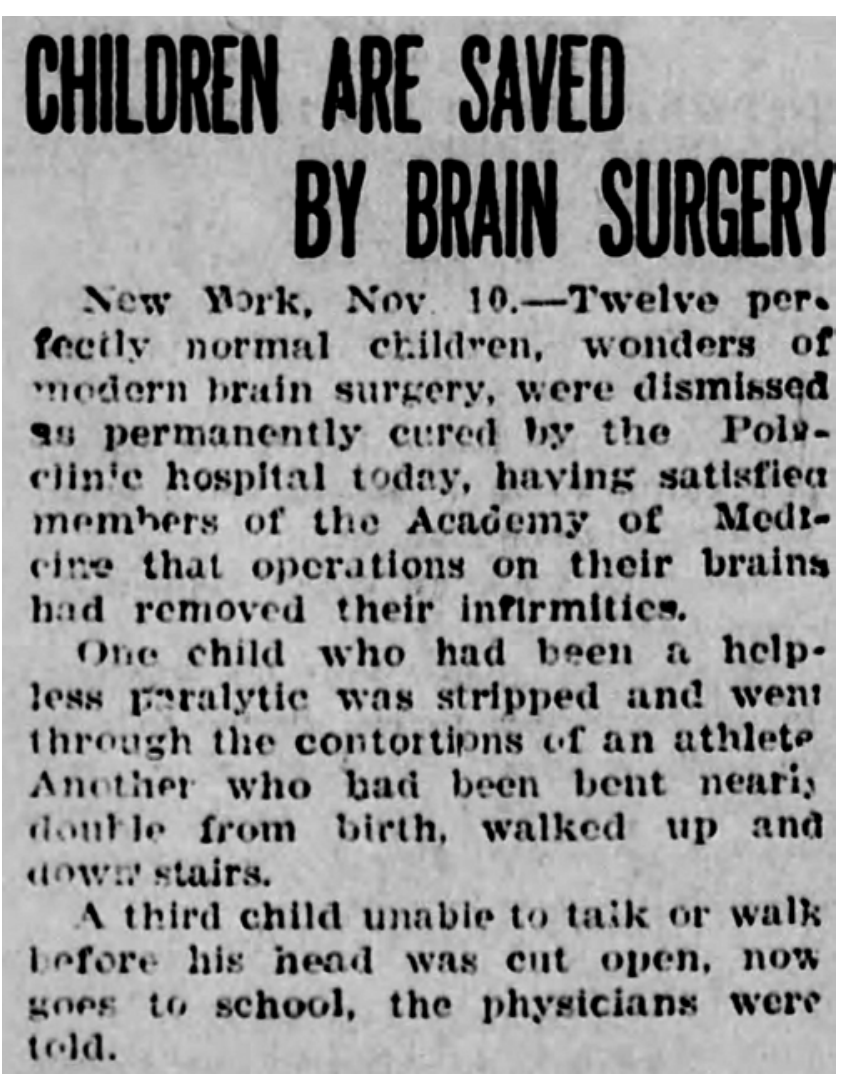

FIG. 7. Sharpe's social media popularity based on his treatment of cerebral palsy. Pittston Gazette, November 10, 1915. Public domain.

known as the "Harvard Nazi." 22,30 In 1920, he married Helen Niemeyer, a native New Yorker, and later they moved to Munich. ${ }^{17}$

Putzi became fascinated by Hitler's dictatorial personality."13,17 After introducing himself to the Führer, Putzi became head of the Nazi foreign press bureau. He saw Hitler as an "unconventional but gifted politician" on the rise, and he was willing to rise with the dictator. ${ }^{17}$ Putzi introduced the dictator to Munich high society and helped finance the publication of Hitler's Mein Kampf. Their friendship and political association lasted through the 1920s and early 1930s. ${ }^{17,22,30}$

Putzi and his family were close to Hitler, who became the godfather of their son Egon. The dictator became a frequent guest in their apartment. Helen recalled, "He was a constant visitor, enjoying the quiet, cozy home atmosphere, playing with my son at intervals, and talking over for hours his plans and hopes for the renaissance of the German Reich." ${ }^{17}$ Putzi played piano for Hitler until late at night to help the dictator calm his nerves at the end of a long day. ${ }^{15}$ Louis P. Lochner of the Associated Press once mentioned a biblical analogy, "Putzi was to Hitler what harp-playing David was to Saul. He eased der Führer out of his frequent fits of depression with his piano playing."10

When Sharpe reached Russia, he spent almost 4 months giving lectures and demonstrating surgical procedures. During his last week, he visited the State Kremlin Palace and was introduced to Premier Stalin by George Yudin, a Soviet surgeon. Sharpe found Stalin to be in good health,

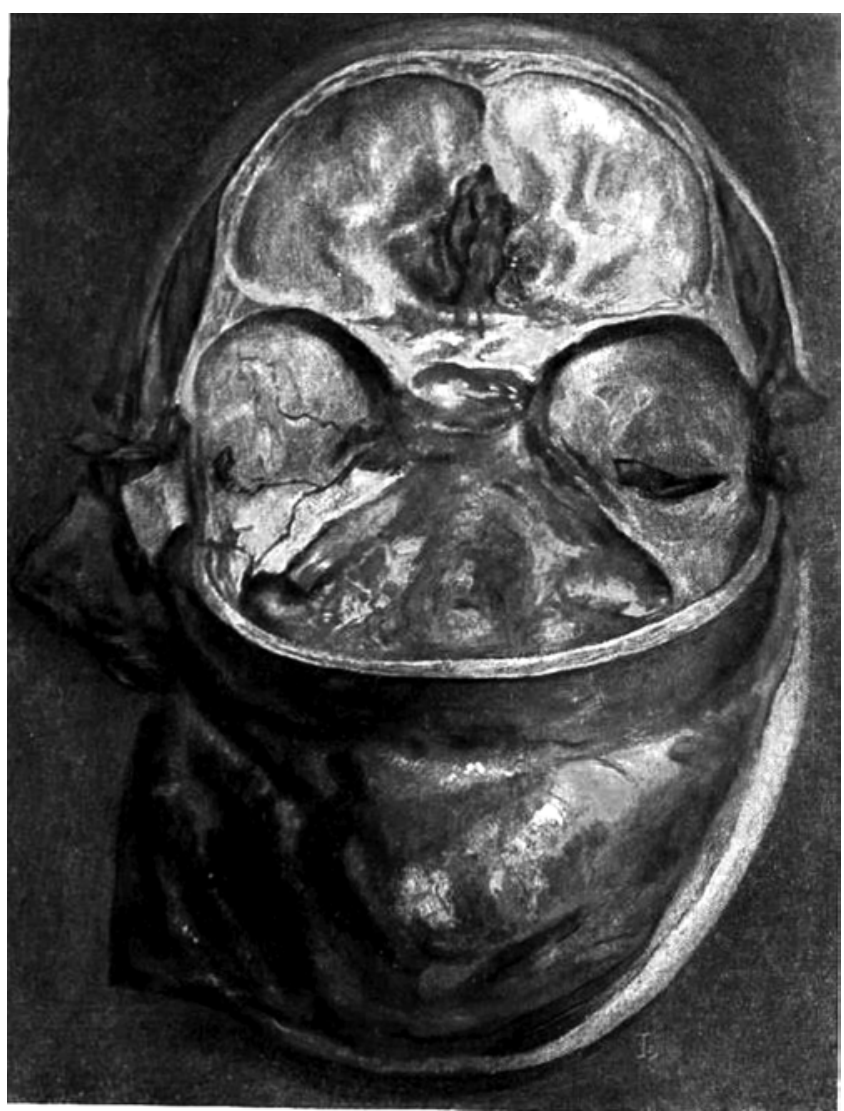

FIG. 8. Sharpe's description of skull fractures. Diagnosis and Treatment of Brain Injuries, 1920. Public domain.

cordial but restrained. Stalin signed papers that made it obligatory for every Soviet doctor to perform an early diagnostic spinal puncture on all newborns who showed signs of intracranial hemorrhage.

\section{Pan-American Association and Hospital}

Before World War I, medical practice in South America had been under the influence of European doctors. Europe was devastated after the war, and Sharpe noticed an increasing interest of Latin American doctors in North America's medical practice. He initiated a collaboration between North and South America, which culminated in the creation of the Pan-American Medical Association. Sharpe and his colleagues frequently flew to Central and South America for meetings and surgical procedures. The group became known as the "Flying Clinic" or "AeroClinic" (Fig. 10). ${ }^{3,4,8}$

In the early years of the Pan-American Association, Sharpe recalled a painful memory related to his problems with alcohol. In 1926, he arrived in Cuba as a guest speaker at the annual meeting of the Cuban National Medical Association. The day he arrived a black Haitian laborer had fallen off a truck and was rendered paraplegic from a thoracic fracture dislocation. At the request of the local physicians, Sharpe agreed to operate on the man, but first he was scheduled to give a lecture at noon, which would be followed by a banquet at 1:30 PM, so the procedure was postponed until 4 PM. The banquet was celebratory 


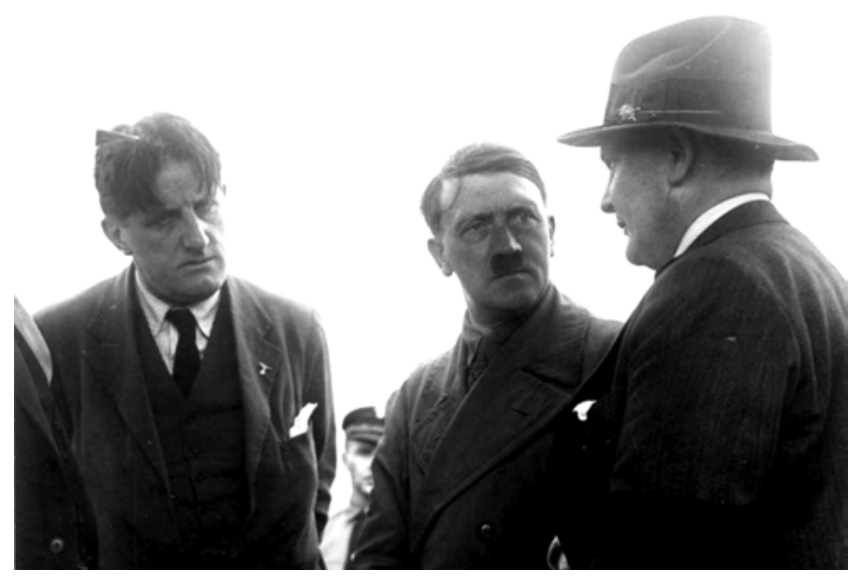

FIG. 9. Ernst Hanfstaengl, Adolf Hitler, and Herman Göring, 1932. Courtesy of German Federal Archives.

and included cocktails, wine, and a series of postprandial rums and liquors, to the extent that Sharpe had completely forgotten about the planned surgery. When he got to the operating room, the patient was already positioned prone and was under ether anesthesia. Although Sharpe had preferred to do the case under a local to avoid the risks of general anesthesia, especially since the patient had been rendered anesthetic by the spinal cord injury, he chose not to say anything for fear of insulting his medical hosts.

Sharpe described what happened next: "No sooner had I made the superficial skin incision over the spine than I noticed that the patient's blood was black, almost syrupy. ... At the moment, I also observed that his skin was black! In my state of alcoholic befuddlement it seemed perfectly logical - the patient was a Negro, therefore his blood would be black!"

Subsequently, the patient stopped breathing. The operation was terminated, but the patient could not be resuscitated and died. The case haunted Sharpe throughout the rest of his life:

It was a humiliating experience. It burns within me to this day - and never a drink of alcohol by me before an operation to this very day of 1952 !

Sharpe became the first president of the Pan-American Medical Association and served 2 consecutive years. He also encouraged the creation of the Pan-American Hospital in New York City. The hospital offered working and training opportunities for Latin American physicians and nurses and also provided health care for the more than 300,000 Spanish-speaking residents. ${ }^{9}$ Sharpe's efforts helped to create the monthly Latin American journal, entitled Revista Médica Panamericana. ${ }^{23}$

\section{The Hammocks}

Sharpe spent his vacation time on his 2,200-acre tract on the eastern shore in North Carolina called the Hammocks, where he enjoyed hunting (quail, turkey, and pheasant) and fishing. He called the place "the peninsular wonderland." There Sharpe developed an extraordinary friendship with John Hurst, the son of a slave. Sharpe considered Hurst to be his best friend (Fig. 11). Sharpe was

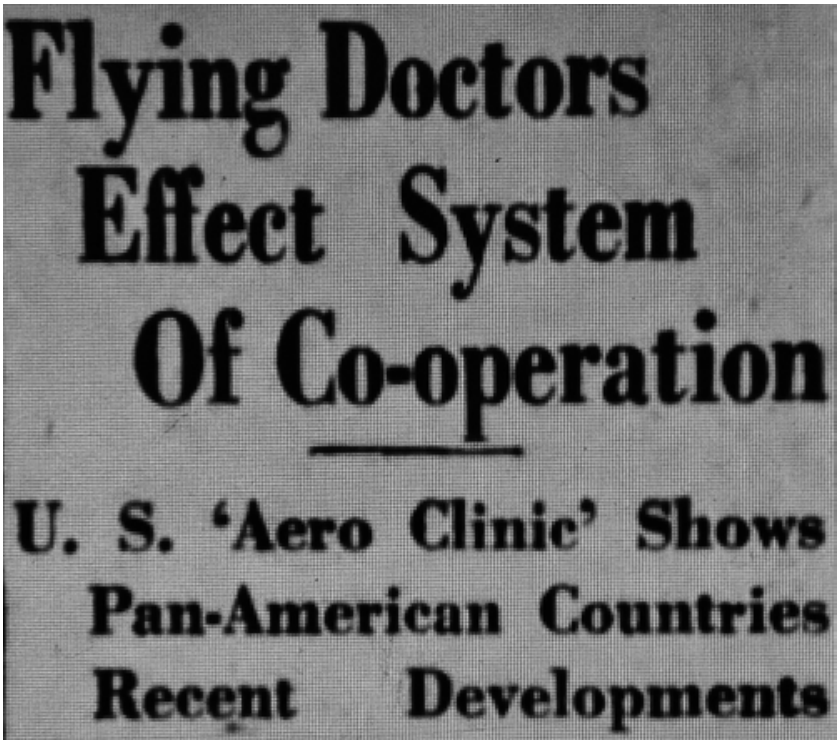

FIG. 10. Sharpe and his colleagues in the Pan-American Medical Association, the "Aero-Clinic." Courtesy of Brooklyn Daily Eagle, 1930.

also close to Hurst's wife Gertrude, who was caretaker of the Hammocks. ${ }^{25}$

In the early spring of 1937, the new East Coast Highway connecting Norfolk with Morehead City, Swansboro, Wilmington, and Charleston would pass directly through The Hammocks' mainland, making it more "valuable" economically but ruining it as a peaceful place for Sharpe

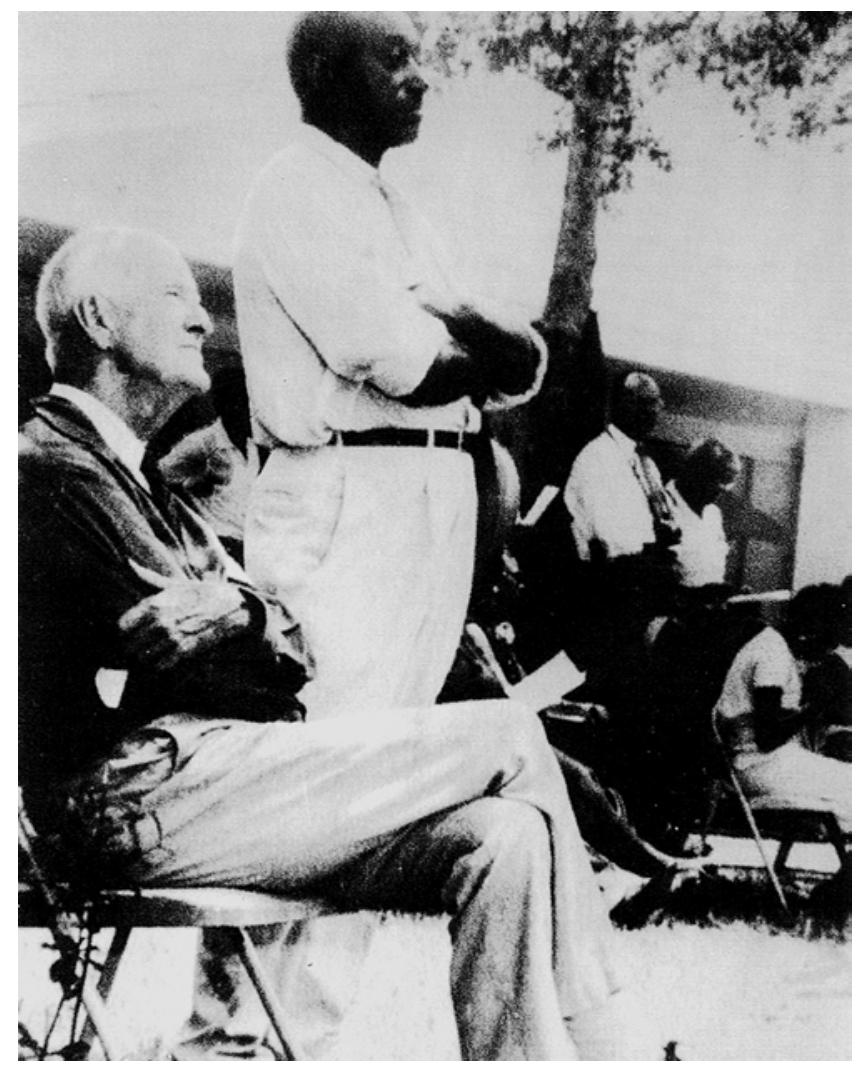

FIG. 11. Sharpe (sitting) and John Hurst at the Hammocks. Courtesy of David Pearson. 
and his family. Sharpe decided to meet with Franklin Roosevelt, his former classmate, hoping to stop the highway project. Ross T. McIntire, FDR's personal physician, set an appointment for their meeting, and Sharpe remembered:

That noon I was ushered into the office of the President of the United States for "three minutes only." It was exciting to me, and FDR was most gracious. When I had told him a few words of my story, he guffawed and shoved his chair back from the desk. "I'm terribly sorry," he said, "but it's just not possible for me to interfere in such matters. I appreciate how you feel - I too am a property owner, and I too would resent such a road, especially if I were trying to preserve it for the welfare purpose you are planning. But there is really nothing I can do." He paused. "However, why not leave the details with my secretary? Possibly something might turn up.

About 2 weeks later, Sharpe received a letter from Gertrude saying the highway project had been suspended.

Beside the Hammocks, Sharpe owned some wooded land in the Fishkill Mountains in New York State and another property in the high Sierras. In 1948, Sharpe and his wife Jo donated their thousand acres in New York to the Herald Tribune Fresh Air Fund for the use of underprivileged children of New York City. A year later, they transferred the Hammocks to approximately 8,000 schoolteachers of the North Carolina Teachers Association, for recreation and education purposes..$^{25}$

\section{Autopsy on His Brother}

Eugene, the oldest of the Sharpe brothers, became a general practitioner who subsequently became a general surgeon. He was an avid outdoorsman and spent much of his free time hunting bear in central Utah. He died in the winter of 1934, at the age of 60, in a fall from a high cliff. Because of the harsh weather, his body was not found until the spring when a trout fisherman identified his decomposing body along with his rifle and a bear skin that he was presumably planning to bring home.

In 1940, Sharpe's other brother Norman developed progressive and incapacitating back pain. One evening when Sharpe and Norman were visiting the Hammocks, Sharpe's friend Hurst brought up the topic of Norman's bad teeth. Norman's teeth were terrible. Hurst felt that if Norman had "all his bad teeth yanked out, he might ketch himself a gal," and then maybe his back pain would have gone away. This made such an impression on Norman that when he returned to New York the next day he checked into a hospital and had all his upper teeth removed in one sitting. The surgery caused him such a violent reaction that he was bedridden for 3 weeks. Not deterred, Norman went ahead and had all his lower teeth removed in the same fashion, again reacting to the surgery the same way, requiring 3 weeks of bed rest to recuperate. Unfortunately, his social life never improved, and his back pain persisted and progressed. Norman lost 70 pounds and there was concern about malignancy. He was examined by 17 doctors, but no diagnosis could be made. As Norman's condition continued to deteriorate, he made his brother promise to have an autopsy performed at the time of his death: "I'd like to know just what this damn thing is!"

By Christmas Eve, Norman had developed pneumonia and died the following day. Although Sharpe had prom- ised him the autopsy, he was unable to secure a pathologist during the holidays. Sharpe made valiant efforts, contacting pathologists in multiple towns and even requesting an autopsy from nonpathologist physicians, but all to no avail. The funeral service was scheduled for 3 PM on New Year's Day. Three hours before the funeral service, Sharpe decided to perform the autopsy on his own brother. The scenario is reminiscent of the autopsy he performed on Cushing's giant, with the unknowing friends and family waiting impatiently for the service to begin in the next room. Sharpe diagnosed diffuse arteriosclerosis as the cause of death. He found chronic infection in the jaw and concluded that the inciting factor in Norman's death was his bad teeth. With the funeral only moments away, Sharpe quickly closed his incisions, filling the empty abdomen with newspapers and clothing from the room so that the body would assume its normal contour. Remembering the promise that he had made to his brother, Sharpe quickly penned a note on a piece of paper and placed it within the chest cavity: "Dear Norman, It was your goddamned teeth! You should have had them out years ago! Love, Clyde."

\section{Conclusions}

Sharpe retired with his wife to St. Petersburg, Florida. He died of cerebral thrombosis at age 77, on March 29, 1960. ${ }^{1,5} \mathrm{He}$ was a brilliant but controversial man. Sharpe was one of the earliest neurosurgeons in the country and was trained by neurosurgical masters. He wrote textbooks and focused his academic interests on the treatment of cerebral palsy and craniocerebral trauma. Sharpe had a global footprint and traveled the world. He operated on the son of the emperor of China and met Hitler and Stalin. He created the Pan-American Medical Association and helped establish the Pan-American Hospital in New York City.

Sharpe was eccentric in his ways and colorful in his personality but fully committed to his profession, honest in his evaluation of himself, and generous with his philanthropy. It is surprising that a man who casts such a large shadow is virtually unknown to modern neurosurgical society.

\section{References}

1. Alexander E Jr: William Sharpe, M.D.-neurosurgeon/entrepreneur. Neurosurgery 22:961-964, 1988

2. Allen WH: Hospital efficiency. Am J Sociol 12:298-318, 1906

3. American Medicine: Men and things: William Sharpe, M.D., F.A.C.S. American Medicine 36:116, 188, 1930

4. Associated Press: "Flying clinic" soars into central America. Scranton Republican. January 28, 1920; 22

5. Associated Press: Noted brain surgeon dies. Hays Daily News. March 30, 1960; 2 (col. 3)

6. Boston Medical and Surgical Journal: Harvard Medical School of China. Boston Med Surg J 170:479-479, 1914

7. Boston Medical and Surgical Journal: Harvard Medical School of China. Boston Med Surg J 175:953-954, 1916

8. Brooklyn Daily Eagle: Flying doctors effect system of cooperation. February 2, 1930; D11

9. Brooklyn Daily Eagle: Spanish-speaking residents of city now have hospital where native tongue is heard. October 23, 1927; 12A

10. Conradi P: Hitler's Piano Player: The Rise and Fall of 
Ernst Hanfstaengl, Confidant Of Hitler, Ally of FDR. New York: Carroll \& Graf, 2004

11. Dagi TF: The management of head trauma, in Greenblatt $\mathrm{SH}$, Dagi TF, Epstein MH (eds): A History of Neurosurgery: In Its Scientific and Professional Contexts. Park Ridge, IL: American Association of Neurological Surgeons, 1997, pp 289-344

12. Greenwood Daily Journal: Brain surgery cures twelve children. November 11, 1915; 1

13. Hanfstaengl E: Hitler: The Missing Years. New York: Arcade, 1994

14. Hartshorn WM: History of the New York Polyclinic Medical School and Hospital. New York: Haddon Craftsmen, 1942

15. Lamb B: Sundays at Eight: 25 Years of Stories from CSPAN's Q\&A and Booknotes. New York: PublicAffairs, 2014

16. Ming-te L: Yuan Shih-K'ai and the 1911 Revolution. Chin Stud Hist 15:123-138, 1982

17. Nagorski A: Hitler's Harvard man: on his way up, the Nazi leader had help from a source steeped in American culture. World War II 28:38-46, 2013

18. New PK, Cheung YW: Harvard Medical School of China, 1911--1916: an expanded footnote in the history of western medical education in China. Soc Sci Med 16:1207-1215, 1982

19. New York Times: Brain operation as paralysis cure: Dr. Sharpe brings children he has treated for city physicians to see. March 17, 1914

20. New York Times: Dr. F.H. Albee heads medical body. December 17, 1927

21. New York Times: Pan-American clinic gets new quarters. August 9, 1929

22. Norwood SH: Legitimating Nazism: Harvard University and the Hitler regime, 1933-1937. Am Jew Hist 92:189-223, 2004

23. Ortiz LP: [Historical elements of neurosurgery in Matanzas 1920-1930.] Rev Med Electronica 28:151-160, 2006 (Span)

24. Pacific Medical Journal: Clinical Society of the New York Polyclinic Medical School and Hospital. Pacific Med J (1889-1917) 46:299-305, 1903

25. Pippin J: Settlement reached in expansion of Hammocks Beach State Park. Jacksonville Daily News. June 16, 2014 (http://www.jdnews.com/news/local/settlement-reached-inexpansion-of-hammocks-beach-state-park-1.333504 ) [Accessed May 12, 2015]
26. Pittston Gazette: Children are saved by brain surgery. November 10,$1915 ; 1$

27. Power DA: The Foundations of Medical History. Baltimore: Williams \& Wilkins, 1931

28. Quest DO, Pool JL: A history of the Neurological Institute of New York and its Department of Neurological Surgery. Neurosurgery 38:1232-1236, 1996

29. Ray BS: The development of neurosurgery in New York City. Bull N Y Acad Med 55:916-938, 1979

30. Sedgwick J: The Harvard Nazi. Boston Magazine 43:55, 2005

31. Sharpe W: Brain Surgeon. The Autobiography of William Sharpe. New York: New York: Viking Press, 1952

32. Sharpe W: Diagnosis and Treatment of Brain Injuries With and Without a Fracture of the Skull. Philadelphia: J.B. Lippincott, 1920

33. Sharpe W, Sharpe N: Neurosurgery: Principles, Diagnosis and Treatment. Philadelphia: J.B. Lippincott, 1928

34. Sharpe W: A new operative treatment for selected cases of cerebral spastic paralysis. J Am Med Assoc 64:482, 1915

35. Sharpe W: Observations in the diagnosis and treatment of brain injuries in adults. J Am Med Assoc 66:1536-1540, 1916

36. Sharpe W: Observations regarding the condition of spastic paralysis due to intracranial hemorrhage. J Nerv Ment Dis 43:355-357, 1916

37. Sharpe W: The operative treatment of fracture of the skull. Chin Med J 26:218-223, 1912

38. Sharpe W: The significance of papilledema in neurosurgery. Laryngoscope 36:411-417, 1926

39. Stedman TL (ed): A new operative treatment for spastic paralysis. Medical Record 86:89-90, 1914

\section{Author Contributions}

Conception and design: both authors. Acquisition of data: both authors. Analysis and interpretation of data: both authors. Drafting the article: both authors. Critically revising the article: both authors. Reviewed submitted version of manuscript: both authors. Study supervision: Cohen.

\section{Correspondence}

Alan R. Cohen, Department of Neurosurgery, Boston Children's Hospital, 300 Longwood Ave., Boston, MA 02115. email: alan. cohen@childrens.harvard.edu. 